\title{
PERSEPSI TENAGA PENDIDIK DAN TENAGA KEPENDIDIKAN TERHADAP PROGRAM BELAJAR DARI RUMAH
}

\author{
Barkat Amiruddin \\ Kementerian Agama Bengkulu Tengah \\ Email: barkatamiruddin@gmail.com
}

\begin{abstract}
Learning from Home Program have started since the covid19 pandemic entered Indonesia. Educators and education staff have implemented this program in schools. The purpose of this study was to determine the perceptions of teaching staff and education staff towards Learning from Home Program, the positive and negative impacts of the Learning from Home Program, and the obstacles in implementing the Learning from Home Program. The research method used is descriptive research with a qualitative approach. This research was conducted in 4 schools in the Central Bengkulu area, with 72 respondents. The results of the study found that most of the teaching staff and education staff did not like the Learning from Home Program, which was $61.1 \%$ or as many as 44 people. Positive impacts of the Home Learning Program, namely: (a) Learning becomes more time-efficient; (b) Train students to be more independent and responsible; (c) Making teachers more creative in making learning media and quizzes and multimedia supporting the learning process; and others. The negative impacts of the Home Learning Program, namely: (a) Reduced communication between teacher and students; (b) Learning becomes more difficult to control; (c) Difficulties in evaluating children; and others. Constraints in the implementation of the Learning from Home Program, namely: (a) Not all students have the tools to support the learning process; (b) Poor internet network in remote areas; (c) Lack of interaction and communication between students and teachers; and (d) There are still students who underestimate online learning.
\end{abstract}

Keywords: Perception, Educators, Educators, Learning from Home Program

\begin{abstract}
Abstrak: Program belajar dari rumah sudah mulai dilakukan sejak pandemi covid19 masuk ke Indonesia. Tenaga pendidik dan tenaga kependidikan telah menerapkan program ini disekolah. Tujuan penelitian untuk mengetahui persepsi tenaga pendidik dan tenaga kependidikan terhadap program belajar dari rumah, dampak positif dan negatif Program Belajar dari Rumah, serta kendala dalam penerapan Program Belajar dari Rumah. Metode penelitian yang digunakan adalah penelitian deskriptif dengan pendekatan kualitatif. Penelitian ini dilakukan di 4 sekolah di daerah Bengkulu Tengah, dengan jumlah responden sebanyak 72 orang. Hasil penelitian ditemukan bahwa sebagian besar Tenaga pendidik dan tenaga kependidikan tidak menyukai Program belajar dari Rumah, yaitu sebanyak 61,1\% atau sebanyak 44 orang. Dampak positif Program Belajar dari Rumah, yaitu: (a) Pembelajaran menjadi lebih hemat waktu; (b) Melatih siswa lebih mandiri dan bertanggung jawab; (c) Membuat guru lebih kreatif dalam membuat media pembelajaran dan kuis serta multimedia pendukung proses pembelajaran; dan lain-lain. Dampak negatif Program Belajar dari Rumah, yaitu: (a) Komunikasi yang berkurang antara guru dan siswa; (b) Pembelajaran jadi lebih susah untuk di control; (c) Kesulitan dalam evaluasi terhadap anak; dan lain-lain. Kendala dalam penerapan Program Belajar dari Rumah, yaitu: (a) Tidak semua siswa mempunyai alat pendukung proses pembelajaran; (b) Buruknya jaringan internet di daerah pedalaman; (c) Kurangnya interaksi dan komunikasi antara siswa dan guru; dan (d) Masih ada siswa yang menganggap remeh terhadap pembelajaran daring.
\end{abstract}

Kata Kunci: Persepsi, Tenaga Pendidik, Tenaga Kependidikan, Program Belajar dari Rumah

\section{PENDAHULUAN}

Sejak pandemi coronavirus (COVID-19) masuk ke Indonesia pada bulan Maret hingga bulan April tahun 2020, data saat artikel ini ditulis, rakyat Indonesi telah 
dikonfirmasi terinfeksi virus sebanyak 4839 positif, dengan 426 orang sembuh, serta 459 orang dinyatakan meninggal (BNPB, 2020). Untuk mencegah penyebaran virus ini pemerintah meluncurkan Program Belajar dari Rumah, sehingga semua sekolah juga menerapkannya. Program ini diluncurkan secara mendadak sehingga terkesan dilakukan tanpa persiapan yang matang. Tenaga pendidik dan tenaga kependidikan sebagai salah satu garis terdepan dalam proses belajar mengajar mengalami banyak kendala dalam penerapannya, hal yang sama juga dihadapi oleh siswa (Tirto.id, 2020).

Salah satu tugas pokok penulis sebagai pengawas madarah yaitu melakukan penilaian dan pembinaan dengan melaksanakan fungsi supervisi, baik supervisi akademik maupun supervisi manajerial (Kementerian Agama Provinsi Jawa Tengah, 2017). Pengawas madrasah harus memastikan proses belajar mengajar dapat berjalan dengan lancar dan baik, khususnya program Belajar dari Rumah yang sedang berlangsung saat ini. Berdasarkan observasi awal bahwa tenaga pendidik dan tenaga kependidikan banyak yang mengeluhkan program ini, sehingga penulis merasa perlu melakukan penelitian lebih lanjut guna mencari solusi yang terbaik guna tetap berjalannya pembelajaran sebaik mungkin. Berangkat dari itu, adapun rumusan masalah yang diangkat dalam artikel ini adalah: 1) Bagaimana persepsi tenaga pendidik dan tenaga kependidikan terhadap program belajar dari rumah, 2) apa dampak positif dan negatif Program Belajar dari Rumah, 3) apa kendala dalam penerapan Program Belajar dari Rumah?.

\section{LANDASAN TEORI}

Persepsi adalah kemampuan otak dalam menerjemahkan stimulus atau proses untuk menerjemahkan stimulus yang masuk ke dalam alat indera manusia. Persepsi manusia terdapat perbedaan sudut pandang dalam penginderaan. Ada yang mempersepsikan sesuatu itu baik atau persepsi yang positif maupun persepsi negatif yang akan mempengaruhi tindakan manusia yang tampak atau nyata (Sugihartono, 2007). Menurut Miftah Toha (2003), faktor-faktor yang mempengaruhi persepsi seseorang adalah sebagai berikut :

a. Faktor internal: perasaan, sikap dan kepribadian individu, prasangka, keinginan atau harapan, perhatian (fokus), proses belajar, keadaan fisik, gangguan kejiwaan, nilai dan kebutuhan juga minat, dan motivasi. 
b. Faktor eksternal: latar belakang keluarga, informasi yang diperoleh,pengetahuan dan kebutuhan sekitar, intensitas, ukuran, keberlawanan, pengulangan gerak, hal-hal baru dan familiar atau ketidak asingan suatu objek (Thoha, 2003).

Tenaga pendidik merupakan tenaga profesional yang bertugas merencanakan dan melaksanakan proses pembelajaran, menilai hasil pembelajaran, melakukan pembimbingan dan pelatihan, serta melakukan penelitian dan pengabdian kepada masyarakat, terutama bagi pendidik pada perguruan tinggi (Indonesia, 2003). Tenaga pendidik atau guru adalah tenaga professional yang dapat menjadikan murid-muridnya mampu merencanakan, menganalisis, dan menyimpulkan masalah yang dihadapi (Nurdin, 2003). Tenaga kependidikan adalah anggota masyarakat yang berusaha mengabdikan diri dan diangkat untuk menunjang penyelenggaraan pendidikan. Tugas tenaga kependidikan itu adalah melaksanakan administrasi, pengelolaan, pengembangan, pengawasan, dan pelayanan teknis untuk menunjang proses pendidikan pada satuan pendidikan (Indonesia, 2003). Berdasarkan uraian tugas tenaga pendidik dan tenaga kependidikan ini dapat disimpulkan bahwa tugasnya sangat vital atas berlangsungnya pembelajaran.

Program Belajar dari Rumah merupakan bentuk upaya Kemendikbud membantu terselenggaranya pendidikan bagi semua kalangan masyarakat di masa darurat COVID19 (Tirto.id, 2020). Program belajar dari rumah ini menggunakan aplikasi atau website yang memanfaatkan teknologi dalam pengaplikasiannya. Adanya program ini mengharuskan seluruh pembelajaran dilakukan secara daring dan tanpa tatap muka antara guru dan siswa.

\section{METODE PENELITIAN}

Pendekatan penelitian ini menggunakan pendekatan kuantitatif karena menggunakan angka, mulai dari pengumpulan data, penafsiran terhadap data tersebut, serta penampilan dari hasilnya (Arikunto, 2005). Metode penelitian merupakan penelitian deskriptif. Penelitian kuantitatif deskriptif digunakan untuk menggambarkan, menjelaskan, atau meringkaskan berbagai kondisi, situasi, fenomena, atau berbagai variabel penelitian menurut kejadian sebagaimana adanya yang dapat dipotret, diwawancara, diobservasi, serta yang dapat diungkapkan melalui bahan-bahan dokumenter (Bungin, 2005). Populasi penelitian yang digunakan adalah tenaga pendidik dan tenaga kependidikan yang berasal dari 4 madrasah yang berada di 
kabupaten Bengkulu Tengah, dengan melibatkan 72 tenaga pendidik dan tenaga kependidikan. Pengumpulan data menggunakan kuisioner dan wawancara.

\section{HASIL DAN PEMBAHASAN}

\section{Persepsi Tenaga Pendidik Dan Tenaga Kependidikan Terhadap Program Belajar Dari Rumah}

Berdasarkan kuisioner yang telah diisi oleh tenaga pendidik dan tenaga kependidikan, data yang diperoleh dengan pertanyaan: Apakah anda menyukai program Belajar dari Rumah?. Jawaban yang diperoleh ternyata $61,1 \%$ atau sebanyak 44 orang menjawab tidak menyukai program Belajar dari Rumah, sementara 38,9\% atau sebanyak 28 orang menjawab menyukai program Belajar dari Rumah. Untuk lebih jelas lagi dapat dilihat pada diagram berikut ini:

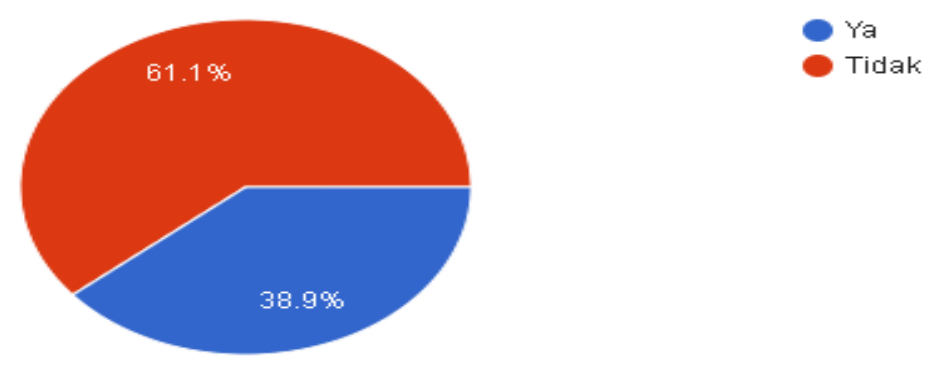

Diagram 1. Data suka/tidak suka program belajar dari rumah

Untuk lebih detail lagi, jawaban tidak menyukai Program belajar dari Rumah berasal dari 11 responden di MAN IC, 15 responden dari MAS An-Nur, 15 responden berasal dari MAS Darul Qalam, dan 3 responden berasal dari MAS Nurul Huda. Jawaban menyukai Program Belajar dari Rumah dijawab oleh 12 responden dari MAN IC, 2 responden dari MAS An Nur, 7 Responden dari MAS Darul Qalam, dan sebanyak 7 Responden berasal dari MAS Nurul Huda. Berdasarkan data ini dapat disimpulkan bahwa tenaga pendidik dan tenaga kependidikan sebagian besar tidak menyukai Program belajar dari Rumah.

\section{Alasan Persepsi Tenaga Pendidik Dan Tenaga Kependidikan Terhadap Program Belajar Dari Rumah}

Pertanyaan alasan pilihan jawaban juga diberikan kepada tenaga pendidik dan tenaga kependidikan di empat sekolah yang diteliti, ditemukan jawaban kurang interaksi dengan siswa sebagai alasan paling banyak dijawab oleh responden, yaitu sebanyak 37 responden atau $51 \%$. Jawaban tidak fokus belajar sebanyak 5 responden atau sebesar $7 \%$. 
Jawaban boros kuota dan tidak kondusif masing-masing dipilih oleh 2 responden atau sebesar 3\%. Ini merupakan alasan jawaban tidak menyukai Program Belajar dari Rumah.

Untuk alasan jawaban menyukai Program Belajar dari Rumah, ditemukan juga berbagai alasan yang beragam, yaitu: waktu dan tempat belajar yang fleksibel dijawab oleh 10 responden atau sebesar 14\%. Untuk jawaban pembelajarannya menarik dipilih oleh 9 responden atau sebesar 12\%. Untuk jawaban praktis dipilih oleh 5 responden atau sebesar 7\%, sedangkan sisanya 2 responden atau sebesar 3\% menjawab komunikatif. Untuk lebih jelasnya dapat dilihat pada diagram berikut ini:

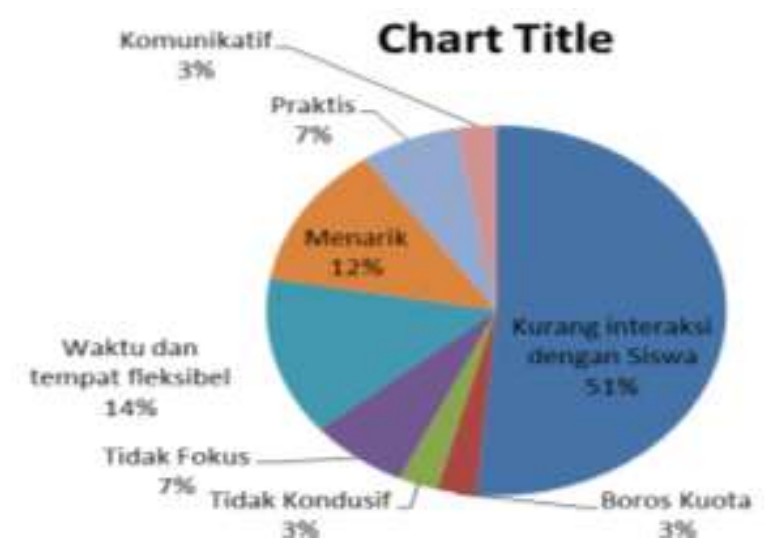

Diagram 2. Alasan pilihan jawaban suka/tidak suka program belajar dari rumah

Berdasarkan data tersebut didapat alasan tidak menyukai Program belajar dari Rumah adalah:

a. Kurangnya interaksi antara guru dengan siswa

b. Situasi belajar yang tidak fokus

c. Suasanya belajar yang tidak kondusif

d. Boros pemakaian kuota internet.

Sedangkan untuk alasan menyukai Program belajar dari Rumah adalah:

a. Waktu dan tempat belajar yang fleksibel

b. Pembelajaran menarik

c. Pembelajaran yang komunikatif

d. Praktisnya pelaksanaan pembelajaran.

\section{Efektifitas Program Belajar dari Rumah}

Pertanyaan selanjutnya yang diajukan terhadap tenaga pendidik dan tenaga kependidikan adalah: Menurut anda efektifkah Program Belajar dari Rumah?. Ternyata mayoritas responden menjawab Program Belajar dari Rumah tidak efektif, sebesar 79,2\% atau sebanyak 57 responden. Sedangkan $20.8 \%$ atau sebanyak 15 responden menjawab 
Program Belajar dari Rumah efektif. Untuk lebih jelas lagi dapat dilihat pada diagram berikut ini:

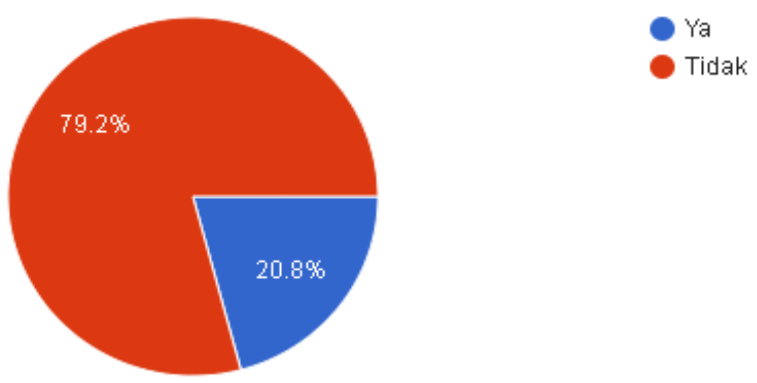

Diagram 3. Efektif/tidak efektif program belajar dari rumah

Berdasarkan data tersebut dapat disimpulkan bahwa Program belajar dari Rumah sebenarnya tidak efektif untuk diterapkan dalam proses belajar mengajar.

\section{Dampak Positif Dan Negatif Program Belajar dari Rumah}

Adapun dampak positif dari Program belajar dari rumah adalah:

a. Pembelajaran menjadi lebih hemat waktu

b. Melatih siswa lebih mandiri dan bertanggung jawab

c. Membuat guru lebih kreatif dalam membuat media pembelajaran dan kuis serta multimedia pendukung proses pembelajaran

d. Guru menjadi lebih terampil dalam melaksanakan pembelajaran secara online

e. Guru mampu menggunakan aplikasi e-learning

f. Dapat mencegah penyebaran virus covid-19

g. Siswa lebih aktif dalam pengerjaan tugas untuk menunjukkan bahwa mereka mampu.

Dampak Negatif dari Program belajar dari rumah adalah:

a. Komunikasi yang berkurang antara guru dan siswa

b. Pembelajaran jadi lebih susah untuk di control

c. Kesulitan dalam evaluasi terhadap anak

d. Pembelajaran hanya memperhatikan aspek kognitif, sehingga aspek afektif dan psikomotorik terabaikan

e. Guru dan siswa harus mengeluarkan uang lebih banyak untuk membeli kuota internet

f. Adanya persepsi buruk orang tua siswa terhadap guru.

\section{Kendala Dalam Penerapan Program Belajar Dari Rumah}

Adapun kedala yang dihadapi oleh tenaga pendidik dalam pelaksanaan program belajar dari rumah adalah: 
a. Tidak semua siswa mempunyai alat pendukung proses pembelajaran, yaitu HP android

b. Buruknya jaringan internet di daerah pedalaman

c. Kurangnya interaksi dan komunikasi antara siswa dan guru, sehingga pembelajaran berjalan kurang baik

d. Masih ada siswa yang menganggap remeh terhadap pembelajaran daring, sehingga mereka tidak mengerjakan tugas yang diberikan.

Pada kuisioner juga diberikan pertanyaan, Apa saran anda bagi Program Belajar dari Rumah?. Disini tenaga pendidik dan tenaga kependidikan memberikan beberapa masukan, yaitu:

a. Sebaiknya Program belajar dari rumah harus juga diikuti oleh persiapan sarana dan prasarana yang memadai

b. Perlu adanya koordinasi antar kepala sekolah, guru, siswa dan wali siswa, agar program belajar dari rumah dapat berjalan dengan efektif

c. Perlu evaluasi secara berkala, agar program belajar dari rumah dapat terus diperbaiki dari waktu ke waktu

d. Perlu adanya intensif bagi guru dan siswa dalam bentuk kuota internet, agar proses belajar mengajar berjalan dengan lancar

e. Sebaiknya ada pelatihan yang diberikan pada guru dan siswa tentang pelaksanaan pembelajaran secara daring.

Tenaga pendidik dan tenaga kependidikan juga memberikan jawaban atas pertanyaan: Pembelajaran seperti apa yang tepat digunakan saat pandemi coronavirus seperti saat ini?. Jawaban yang diberikan juga beragam, yaitu:

a. Belajar dalam bentuk penugasan dari rumah saja

b. Pembelajaran berbasis karakter dan spiritual

c. Pembelajaran online dengan melibatkan wali murid secara aktif

d. Pembelajaran kontekstual

e. Belajar dirumah dalam bentuk penugasan, tugas dikumpulkan sekali seminggu ke sekolah oleh siswa.

\section{KESIMPULAN}

Persepsi tenaga pendidik dan tenaga kependidikan terhadap program belajar dari rumah menunjukkan sebagian besar tidak menyukai Program belajar dari Rumah, dengan 
rincian $61,1 \%$ atau sebanyak 44 orang menjawab tidak menyukai program Belajar dari Rumah, sementara 38, 9\% atau sebanyak 28 orang menjawab menyukai program Belajar dari Rumah.

Dampak positif Program Belajar dari Rumah, yaitu: (a) Pembelajaran menjadi lebih hemat waktu; (b) Melatih siswa lebih mandiri dan bertanggung jawab; (c) Membuat guru lebih kreatif dalam membuat media pembelajaran dan kuis serta multimedia pendukung proses pembelajaran; (d) Guru menjadi lebih terampil dalam melaksanakan pembelajaran secara online; (e) Guru mampu menggunakan aplikasi e-learning; dan (f) Dapat mencegah penyebaran virus covid19. Dampak negatif Program Belajar dari Rumah, yaitu: (a) Komunikasi yang berkurang antara guru dan siswa; (b) Pembelajaran jadi lebih susah untuk di control; (c) Kesulitan dalam evaluasi terhadap anak; (d) Pembelajaran hanya memperhatikan aspek kognitif; (e) Guru dan siswa harus mengeluarkan uang lebih banyak untuk membeli kuota internet; (f) Adanya persepsi buruk orang tua siswa terhadap guru; dan (g) Siswa lebih aktif dalam pengerjaan tugas untuk menunjukkan bahwa mereka mampu.

Kendala dalam penerapan Program Belajar dari Rumah, yaitu: (a) Tidak semua siswa mempunyai alat pendukung proses pembelajaran; (b) Buruknya jaringan internet di daerah pedalaman; (c) Kurangnya interaksi dan komunikasi antara siswa dan guru; dan (d) Masih ada siswa yang menganggap remeh terhadap pembelajaran daring.

\section{SARAN}

Adapun saran yang ingin sampaikan, 1) bagi pemerintah agar menyiapkan sarana dan prasara Program Belajar dari Rumah, 2) bagi sekolah agar memberikan fasilitas Program Belajar dari Rumah,3) guru agar meningkatkan kemampuan mengajar secara daring, 4) dan siswa agar mengikuti Program Belajar dari Rumah dengan serius, 5) serta wali murid agar mendampingi anak saat melaksanakan Program Belajar dari Rumah.

\section{DAFTAR PUSTAKA}

Arikunto, S. (2005). Prosedur Penelitian: Suatu Pendekatan Penelitian. Jakarta: Rineka Cipta.

BNPB. (2020). Virus Corona COVID-19. Retrieved from https://www.covid19.go.id/

Bungin, B. (2005). Metodologi Penelitian Kuantitatif: Komunikasi, Ekonomi, dan Kebijakan Publik Serta Ilmu-Ilmu Sosial Lainnya. Jakarta: Kencana.

Kementerian Agama Provinsi Jawa Tengah. (2017). Pengawas Harus Tahu Tugas dan 
Fungsinya.

Retrieved

from

https://jateng.kemenag.go.id/warta/berita/detail/pengawas-harus-tahu-tugas-danfungsinya

Nurdin, S. dan M. B. U. (2003). Guru Profesional Implementasi dan Kurikulum. Jakarta: Ciputat Press.

Sugihartono, D. (2007). Psikologi Pendidikan. Yogyakarta: UNY Press.

Thoha, M. (2003). Perilaku Organisasi: Konsep Dasar dan Aplikasinya. Jakarta: PT. Raya Grafindo Persada.

Tirto.id. (2020a). Jadwal Belajar dari Rumah TVRI 14 April: Ada Matematika dan Sains. Retrieved from https://tirto.id/jadwal-belajar-dari-rumah-tvri-14-april-adamatematika-dan-sains-eNa4

Tirto.id. (2020b). Segudang Masalah Belajar dari Rumah karena Corona COVID-19. Retrieved from https://tirto.id/segudang-masalah-belajar-dari-rumah-karenacorona-covid-19-eGqQ

Undang-Undang Republik Indonesia. (2003). Undang-Undang Republik Indonesia Nomor 20 Tahun 2003 Tentang Sistem Pendidikan Nasional. Jakarta: Sekretariat Negara. 